\title{
KONSEP DASAR SISTEM INFORMASI MANAJEMEN DAN EVALUASI PERKULIAHAN DALAM SISTEM INFORMASI MANAJEMEN
}

Oeh

\author{
Aulina Gusti Mardhiyah
}

Aulinagusty97@gmail.com

\begin{abstract}
Abstrak
Untuk meningkatkan kualitas pendidikan di suatu instansi pendidikan dilakukan dengan cara evaluasi secara terus menerus disetiap proses perkuliahan tiap semesternya. Hal ini dilakukan sebagai acuan dari proses sebelumnya untuk perubahan proses selanjutnya. Sistem informasi manajemen merupakan sarana yang dibutuhkan dalam membantu proses evaluasi perkuliahan.
\end{abstract}

Kata kunci : pendidikan, perkuliahan, evaluasi, system informasi manajemen

\section{Latar belakang}

Perubahan yang cepat dibidang teknologi informasi telah mengubah proses suatu organisasi pada masa yang akan datang. Dengan perkembangan ilmu pengetahuan dan teknologi saat ini semakin meningkat yang menuntut instansi pendidikan dapat menyesuaikan dengan perkembangan zaman. Di Indonesia saat ini, banyak instansi pendidikan yang mempengaruhi sumber daya manusia yang memiliki kuantitas dan kualitas yang dihasilkan SDM tersebut yang terkait dalam manajemen pendidikan lainnya. Hal ini bisa dilihat dari kegiatan perkuliahan yang terjadi di instansi pendidikan tersebut.

Untuk meningkatkan kuantitas dan kualitas SDM instansi pendidikan akan terus-menerus melakukan evaluasi disetiap kegiatan perkuliahan untuk meningkatkan kualitas pendidikan dan dapat bertahan didunia kerja. Hal ini dijadikan sebagai acuan dari proses sebelumnya yang kurang optimal untuk proses berikutnya. Banyak hal-hal yang harus di evaluasi setiap periodenya agar segala sesuatu dapat terlaksana dengan baik. 


\section{Pembahasan}

\section{Sistem informasi manajemen}

Menurut (Rusdiana \& Irfan, 2014) Pengertian system informasi manajemen adalah system yang menyediakan informasi guna mendukung operasi manajemen serta pengambilan keputusan sebuah organisasi. Sistem informasi manajemen merupakan sebuah bidang yang mulai berkembang sejak tahun 1960-an. Sistem informasi manajemen juga dikenal dengan ungkapan lain, seperti "sistem informasi", "sistem pemrosesan informasi", "sistem informasi dan pengambilan keputusan". Sistem Informasi Manajemen menggambarkan suatu unit atau badan khusus yang bertugas untuk mengumpulkan berita dan memprosesnya menjadi informasi untuk keperluan manajerial organisasi dengan memakai prinsip sistem.

Tujuan dari system manajemen adalah :

1. Menangkap data

Yaitu untuk informasi operasional dalam mengambil suatu keputusan dari berbagai sumber eksternal dan internal organisasi

2. Pengolahan data

Yaitu, data yang diperlukan sebagai perencanaan, pengorganisasian, koordinasi, dan pengendalian data operasional yang meliputi ( membuat perhitungan data, menyortir data, merangkum data, mengklasifikasikan data).

3. Penyimpanan, penggunaan dan penyebaran informasi

Hal ini dilakukan agar bisa digunakan untuk masa yang akan datang.

Menurut (Rusdiana \& Irfan, 2014) Tujuan sistem informasi manajemen, diantaranya menyediakan informasi yang dipergunakan dalam perhitungan harga pokok jasa, produk dan tujuan lain yang diinginkan manajemen, menyediakan informasi yang dipergunakan dalam perencanaan, pengendalian, pengevaluasian, dan perbaikan berkelanjutan, menyediakan informasi untuk pengambilan keputusan. 
Manfaat system informasi manajemen menurut (Widyanti, 2006):

1. Meningkatkan kualitas sumber daya manusia

2. Meningkatkan efektifitas dan efisiensi data secara akurat dan realtime.

3. Memudahkan pihak manajemen untuk melakukan perencanaan, pengarahan, pengawasan, dan pendelegasian kerja.

4. Meningkatkan produktifitas dan penghematan biaya dalam sebuah organisasi tertentu.

5. Mengembangkan proses perencanaan yang efektif.

6. Menetapkan investasi yang akan diarahkan pada sistem informasi.

7. Memperbaiki produktivitas dalam aplikasi pengembangan dan pemeliharaan sistem.

8. Mengidentifikasi kebutuhan akan keterampilan pendukung sistem informasi.

Adapun kerugian dari sistem informasi manajemen, yaitu kekurangan sistem informasi sehingga mudah melakukan plagiat, kkurangnya berinteraksi dengan lingkungan, ketergantungan, dan halhal yang tradisional ditinggalkan karena kemajuan sistem informasi dan kemajuan zaman.

Implementasi system informasi manajemen dalam manajemen sekolah:

Penggunaan system informasi manajemen dapat memberikan nilai tambah dalam proses pembelajaran dan pengelolaan sekolah lainnya. Dalam pemanfaatan system informasi manajemen diahrapkan tingkat daya piker serta kreativitas guru dan peserta didik beserta masyarakat dapat berkembang. Pada pelaksanaan implementasi system informasi manajemen sekolah, suatu system dikatakan baik dan normal apabila semua komponen sekolah mulai dari guru, bimbingan konseling, tata usaha, bendahara dan juga kepala sekolah bisa menggunakan dan memanfaatkan fasilitas sesuai dengan kebutuhan masing-masing dan tidak tergantung pada administrator sekolah. 


\section{System informasi manajemen dan evaluasi perkuliahan}

SIM merupakan kunci dari bidang manajemen yang dapat memproses dan menggolah data menjadi bentuk informasi dan dapat digunakan dalam mendukung keputusan. SIM mempunyai banyak jenis salah satu diantaranya adalah SIM yang digunakan di instansi pendidikan, dari SIM perkuliahan SIM dibuat untuk memudahkan top management dalam usaha pengevaluasian seluruh kegiatan manajemen dalam proses perkuliahan agar dapat meningkatkan mutu pendidikan (Agustiandra \& Sabandi, 2019).

Dalam meningkatkan mutu pendidikan dilakukan dengan proses pengambilan keputusan yang berkaitan dengan instansi pendidikan atau perguruan tinggi tersebut, seperti pembagian dan kelayakan mata kuliah, pembagian tugas pengajaran, pengambilan absen dan pembagian tugas individu mahasiswa dan lain sebagainya. Jika dilakukan secara manual dan standar tentu proses pengambilan keputusan tersebut tidak efektif, karena informasi dari data tersebut sangatlah penting untuk melakukan evaluasi berikutnya.

Dengan demikian SIM yang dipercaya dapat bertanggung jawab terhadap ketersediaan data-data yang berkaitan dengan perkuliahan di suatu instansi perguruan tinggi. Seperti rangkuman perkuliahan untuk mengevaluasi kinerja dosen pengajaran, nilai mahasiswa, persentase kehadiran dosen dan persentase kehadiran mahasiswa per periode pendidikan berikutnya. Dengan SIM dapat mempermudah evaluasi perkuliahan dari periode sebelumnya ke periode berikutnya agar proses perkuliahan dapat berjalan dengan baik (Lipursari, 2013).

\section{kesimpulan}

Sistem Informasi Manajemen dapat mempermudah segala proses pengolah data maupun dalam pengambilan keputusan untuk mengevaluasi proses perkuliahan dari satu periode ke periode berikutnya demi kemajuan Sumber Daya Manusia yang berkualitas dan mampu bertahan di dunia kerja. 
Usaha instansi pendidikan untuk terus-menerus meningkatkan kualitas pendidikannya agar sumber daya manusia yang dihasilkan berkualitas tinggi dan dapat bertahan di dunia kerja, dapat dilakukan dengan cara evaluasi secara menerus-menurus terhadap keseluruhan proses perkuliahan yang terjadi setiap semesternya. Sistem informasi manajemen pendidikan adalah suatu sarana yang diharapkan dapat membantu proses evaluasi.

Sistem informasi manajemen mutlak diperlukan dalam pengambilan keputusan yang logis sehingga membutuhkan pemahaman tentang masalah dan pengetahuan mengenai laternatif pemecahannya. Informasi yang lebih tepat menghasilkan keputusan yang lebih baik. Kualitas suatu informasi tergantung dari tiga hal yaitu, informasi harus akurat, tepat waktu dan relevan.

\section{Referensi}

Agustiandra, V., \& Sabandi, A. (2019). Persepsi Guru Terhadap Penerapan Sistem Informasi Manajemen Akademik Di Sekolah Menengah Kejuruan (Smk) Negeri 3 Padang. Jurnal Bahana Manajemen Pendidikan, 8(I), 1-8. Retrieved from http://ejournal.unp.ac.id/index.php/bahana/article/view/103704

Lipursari, A. (2013). Peran Sistem Informasi Manajemen (SIM) Dalam Pengambilan Keputusan. Jurnal STIE Semarang, 5(1), 26-37. https://doi.org/10.1017/CBO9781107415324.004

Rusdiana, \& Irfan, M. (2014). Sistem Informasi Manajemen. Bandung: CV Pustaka Setia.

Widyanti, Y. (2006). Sistem Informasi Manajemen Dan Evaluasi Perkuliahan. Jurnal Seminar Nasional Aplikasi Teknologi Informasi 2006 (SNATI 2006), 57-60. Retrieved from https://media.neliti.com/media/publications/126259-ID-sistem-informasi-manajemen-danevaluasi.pdf 